\title{
Ovarian Squamous Cell Tumor
}

National Cancer Institute

\section{Source}

National Cancer Institute. Ovarian Squamous Cell Tumor. NCI Thesaurus. Code C40092.

A squamous cell tumor that arises from the ovary and is not associated with a germ cell tumor. 